\title{
Effect of Black Tea Polyphenol on Cell-ECM Interaction and MMP
}

\author{
Nabanita Bhattacharyya1, Subhajit Mondal'1, Shuvojit Moulik¹, Sathi Paul', \\ Shreoshi Bhattacharrya ${ }^{1}$, Alok Kumar Hazra' ${ }^{1}$, Md. Nasim Ali ${ }^{2}$, Anjan Adhikari ${ }^{3}$, \\ Amitava Chatterjee ${ }^{1^{*}}$
}

\author{
${ }^{1}$ Ramakrishna Mission Vivekananda University, IRDM, Kolkata, India \\ ${ }^{2}$ B.C.K.V, Kalyani, India \\ ${ }^{3}$ R.G. Kar Medical College, Kolkata, India \\ Email: *amitavachatterjee24@gmail.com
}

How to cite this paper: Bhattacharyya, N., Mondal, S., Moulik, S., Paul, S., Bhattacharrya, S., Hazra, A.K., Ali, Md.N., Adhikari, A. and Chatterjee, A. (2017) Effect of Black Tea Polyphenol on CellECM Interaction and MMP. American Journal of Plant Sciences, 8, 856-866. https://doi.org/10.4236/ajps.2017.84058

Received: February 2, 2017

Accepted: March 26, 2017

Published: March 30, 2017

Copyright $\odot 2017$ by authors and Scientific Research Publishing Inc. This work is licensed under the Creative Commons Attribution International License (CC BY 4.0).

http://creativecommons.org/licenses/by/4.0/

\begin{abstract}
Tea is one of the most widely consumed beverages in the world. Black tea, obtained from the leaves of Camellia sinensis is the preferred beverage in India and in most western countries. Epidemiological studies on black tea and cancer are limited. However, preliminary studies indicate a positive correlation between black tea consumption and a lower incidence of breast and ovarian cancer. In the present communication, we wanted to see the effect of black tea extract and the polyphenol theaflavin on cell-ECM interaction, MMP activity etc. to strengthen the anti-cancer effect of black tea.
\end{abstract}

\section{Keywords}

Black Tea, Polyphenol, MMP, ECM, Cancer

\section{Introduction}

Tea is one of the most widely consumed beverages in the world. Black tea, obtained from the leaves of Camellia sinensis is the preferred beverage in India and in most western countries [1] [2]. Theaflavins are anti-oxidant polyphenols formed via co-oxidation of pairs of epimerized catechins during fermentation of tea leaves in black tea and account for $2 \%-6 \%$ of dry weight. Theaflavins are characterized by benzotropolone ring structure and contribute to the unique taste of black tea. Principal theaflavins include theaflavin (TF-1), theaflavin-3-gallate (TF-2A), theaflavin-3'-gallate (TF-2B), and theaflavin-3, 3'-digallate (TF-3) [1] [3]. Theaflavins are the major antioxidant constituents of black tea, inhibiting free radical generation and pro-oxidative enzyme activities and chelating metal ions to prevent lipid peroxidation. TF-3 has also been shown to possess a higher 
antioxidative activity than catechins, including epigallocatechin gallate (EGCG) [1] [2] [4].

Epidemiological studies on black tea and cancer are limited. However, preliminary studies indicate a positive correlation between black tea consumption and a lower incidence of breast and ovarian cancer [5] [6]. A number of studies have indicated that black tea polyphenols possess anti-inflammatory and antitumorigenic properties, can inhibit proliferation and induce apoptosis in various tumours, including skin and colon cancers [6] [7].

Tumour invasion and formation of secondary tumours require coordinated matrix degradation and modulation of cell-cell and cell matrix attachment. Matrix metalloproteinases (MMPs), a family of zinc dependant endopeptidases, degrade various extra cellular matrix (ECM) components, creating pathways through which tumour cells can invade [8] [9]. MMPs are synthesised as inactive pro-MMPs; activation requires proteolytic removal of the prodomain. MMP-2 (gelatinase A), a $72 \mathrm{kDa}$ type IV collagenase, is activated at the tumour cell surface by an "activation complex" composed of membrane type-1 matrix metalloproteinase (MT1-MMP), tissue inhibitor of metalloproteinase-2 (TIMP-2) and pro-MMP-2 [8] [9] [10] [11]. MMP activity is regulated in vivo by cellular activators and inhibitors e.g. extra-cellular matrix metalloproteinase inducer (EMMPRIN) which upregulates MMP activity and tissue inhibitors of matrix metalloproteinases (TIMPs) which inhibit their activity [8] [9].

Elevated expression and activity of MMPs (e.g. MMP-2) strongly correlate with increased metastatic potential, tumour spread and poor prognosis in a number of cancers including melanomas, breast, lung, thyroid, oral, stomach and colon carcinomas [8] [9] [12] [13] [14]. MMPs play multiple roles in promoting tumour progression by increasing cancer cell growth, migration, metastasis and angiogenesis. Numerous studies indicate that highly invasive cells become less aggressive when MMP expression or activity is reduced, making MMPs promising targets for compounds with anti-metastatic and anti-tumorigenic properties. Black tea polyphenols, including theaflavin and its derivatives, down regulate MMP and urokinase expression in human stomach and colon carcinomas and inhibit MMP-2 and MMP-9 activity in mouse Lewis lung carcinoma cells, thus inhibiting tumour invasion and metastasis [15] [16].

Theaflavin downregulates MMP-2 and MT1-MMP expression and activity and upregulate TIMP-2 levels in A375 human melanoma cells has been reported [17]. Binding of epidermal growth factor receptor (EGFR), a member of erbB family of tyrosine kinase receptors, to its ligands leads to phosphorylation of receptor tyrosine kinases including focal adhesion kinase (FAK) and subsequent activation of signal transduction pathways involved in regulating cellular proliferation, differentiation and survival [18] [19]. Upregulation of EGFR mediated signalling has been associated with poor prognosis and decreased survival in cancer and EGFR has been shown to increase MMP expression and metastasis in human breast cancer cells [18] [20]. TF-3, a theaflavin derivative, has been reported to induce EGFR downregulation and EGF-induced EGFR autophos- 
phorylation in mouse epidermal cell line JB6Cl41 and may exert its chemopreventive effects through the downregulation of EGFR [21]. Integrins are a family of transmembrane heterodimeric proteins which mediate cell adhesion to a variety of ECM and plasma proteins (e.g. fibronectin, fibrinogen). Integrin receptors play important roles in cell anchoring and are critically involved in multiple signal transduction cascades [22] [23]. Theaflavin and its derivatives have been reported to reduce adhesion of MO4 cells to laminin and adhesion of A375 melanoma cells fibronectin, vitronectin and laminin via integrin receptors [17] [24]. Cytoskeletal components like actin filaments and microtubules play an important role in regulation of cell motility and migration [22]. Microtubule targeting agents have a broad spectrum of activity against both haematological malignancies and solid tumours [25]. Theaflavins have been reported to act as microtubule depolymerizers and disrupt the microtubule network, leading to by alteration of cellular morphology and apoptosis in human cervical cancer HeLa cells [26].

FAK acts as a transducer of integrin-growth factor stimulated signals to downstream targets like extracellular signal related kinase (ERK), phosphoinositol-3-kinase (PI-3K), c-Jun kinase (Jnk) and other mitogen activated protein kinase (MAPK) cascades [22] [27]. Signalling through FAK, ERK, PI-3K and other MAPK pathways can increase MMP expression and activity and also influence cytoskeletal organization and migration. FAK is overexpressed in invasive human carcinomas and activation of FAK plays an important role in cell migration [22] [27] [28]. Nuclear transcription factor $\kappa \beta$ (NF- $\kappa \mathrm{B})$, a dimeric transcription factor, is retained in the cytosol in the form of complexes with inhibitory proteins and upon activation, translocates to the nucleus. Signalling through NF- $\kappa B$ plays an important role in inflammation, invasion, angiogenesis and regulation of MMPs. Many malignant tumours display constitutive NF- $\kappa B$ activation that allows malignant cells to escape apoptosis and resist the action of chemotherapeutic agents [29].

The theaflavins, major components of black tea extract, exert multiple roles on intracellular signalling pathways. TF-2 has been reported to downregulate TNF- $\alpha$ and NF- $\kappa B$, preventing inflammation and inducing apoptosis [30]. Theaflavin prevents IL- 6 and ICAM-1 expression through blockade of NF- $\kappa$ B and MAPK signalling pathways in bone marrow-derived macrophages [31]. Theaflavin and black tea polyphenols have been reported to downregulate levels of FAK and ERK in A375 melanoma cells and inhibit FAK, ERK 1/2 and c-Jun [17] [32]. Theaflavins prevent inflammation in bowel diseases by inhibition of integrin linked kinases (ILK) and NF- $\kappa$ B signalling pathways [33]. Pretreatment with TF-3 led to inhibition of ERK phosphorylation and AP-1 activation in JB6Cl41 cells and downregulated anchorage-independent cell transformation [21]. Specific inhibition of MAP kinases by theaflavins has been demonstrated in mouse epidermal JB6 cells and the H-ras-transformed cell line 30.7b Ras 12. TF-3 downregulated phosphorylation of ERK $1 / 2$ and MEK1/2 and decreased Raf-1 expression levels [34]. Apoptosis or programmed cell death can remove 
damaged or infected cells which pose a threat to the organism's integrity. p53, the product of tumour suppressor gene TP53, has been implicated in control of cell proliferation and tumour progression, as well as in the maintenance of genome integrity in response to DNA-damaging events [35]. Treatment with black tea polyphenols has been shown to induce apoptosis in prostate cancer cells by induction of p53 and down-regulation of NF- $\kappa \mathrm{B}$ activity [36]. Theaflavins have been reported to induce apoptosis in mammary epithelial carcinomas through inhibition of PI-3K-Akt-pBad survival pathway [37]. Theaflavin and extracts from black tea have been shown to induce apopotosis in human leukemic cell lines HL-60 and K-562 [40].

In the present communication we wanted to see the effect of black tea extract and the polyphenol theaflavin on cell-ECM interaction, MMP activity etc. to strengthen the anti-cancer effect of black tea.

\section{Materials and Methods}

\subsection{Materials}

Black Tea (Darjeeling variety), B16F10 cells, gelatin and other biochemicals from Sigma, USA, different antibodies are from Santa Cruz, USA

\subsection{Tea Extract}

10 gms of Tea were added to a sterile tube adding $100 \mathrm{ml}$ of distilled water and were percolated for $1 \mathrm{hr}$ at $90^{\circ} \mathrm{C}$. The suspension was run at 10,000 rpm for $10 \mathrm{mins}$ at room temp and the clear supernatant was saved and used as black tea extract.

\subsection{Cell Adhesion Assay}

B16F10 cells were grown in DMEM medium (10\% FCS). 300,000 cells were collected, washed and grown in DMEM (without FCS) in presence of 20/40/80 ul of tea extract $/ \mathrm{ml}$ or $20 / 40 / 80 \mu \mathrm{g}$ of theaflavin/ml for 24 and $48 \mathrm{hrs}$. Cells were collected and cell adhesion assay was performed in a fibronectin coated $(1 \mu \mathrm{g} / \mathrm{ml})$ 96 well plate (in trplicate). Controls were run side by side [11] [17].

\subsection{Immunoblot}

B16 cells were treated with tea extract and or Theaflavin for $48 \mathrm{hrs}$ in DMEM. The cells were collected, extracted and the protein concentration was measured. $100 \mu \mathrm{g}$ of proteins were then run on SDS-PAGE and transferred onto nitrocellulose membrane. The immune blot was developed with respective primary antibodies (Nf- $\kappa$ B, ERK1/2, PI-3K) followed by $2^{\text {nd }}$ antibody coupled to alkaline phosphatase. The colour was developed with NBT/BCIP [11] [17].

\subsection{Zymography}

The culture (DMEM without FCS) medium from cell adhesion assay was saved and MMPs of control and experimental dishes were concentrated using gelatin-sepharose beads. The MMPs adsorbed was released in Lammeli's buffer without B-mercaptoethanol and subjected to zymography. Zymography was also 
done with human salivary MMPs incubating it with black tea extract and theaflavin separately (in vitro) for $30 \mathrm{mins}$ at $37^{\circ} \mathrm{C}$ [11] [17]. We also assayed salivary MMP in vivo. The volunteer was requested to donate $0.5 \mathrm{ml}$ of normal saliva and then after collection the volunteer was requested to drink $200 \mathrm{ml}$ of black tea liquor without milk and sugar. After 30 mins the saliva of the same volunteer was collected. The control and the experimental saliva (100 $\mu \mathrm{g}$ proteins) were subjected to zymography.

\subsection{Immunocytochemistry}

B16F10 cells were grown on clean glass slides. The cells were then washed and incubated with $3 \% \mathrm{BSA}$ blocking buffer for $1 \mathrm{hr}$ at $37^{\circ} \mathrm{C}$ followed by incubation with alfa5 monoclonal antibody for 1 and half hour. The cells were then washed $\times 3$ with PBS and then incubated with $2^{\text {nd }}$ antibody coupled to FITC for $1 \mathrm{hr}$ at $37^{\circ} \mathrm{C}$. The cells were washed $\mathrm{x} 5$ with PBS and observed under fluorescence microscope [11] [17].

\section{Results}

\subsection{Cell Adhesion Assay}

Cell adhesion assay (Figure 1(a), Figure 1(b)) clearly shows that treatment of B16F10 cells with black tea extract $(20,40,80 \mu \mathrm{l} / \mathrm{ml})$ or theaflavin $(20,40,80$ $\mu \mathrm{g} / \mathrm{ml}$ ) in DMEM medium (without FBS) for 24 and $48 \mathrm{hrs}$ affect the adhesion of tumor cells to ECM protein fibronectin drastically along with time and concentrations.

\subsection{Zymography}

Zymogram shows clearly the 72 and $64 \mathrm{kD}$ pro and activated MMP-2 (Figure 2(a), Figure 2(b)). After 24 and $48 \mathrm{hrs}$ of treatment in case of black tea extract the activated $68 \mathrm{kD}$ band was absent within $48 \mathrm{hrs}$ but in case of theaflavin treated cells both the pro and activated bands of MMP-2 were absent within 48 hrs of treatment. Figure 2(c) shows the control salivary MMP (C) and black tea extract (1) and theaflavin (2) treated salivary MMP activity (in vitro) and tea extracts in vivo (3). Figure 2(d) shows Control (C), Fibronectin-B16F10 cells interaction (1), alfa5 antibody treated B16F10 cells (2).

\subsection{Immunocytochemistry}

To see the presence of alfa5betal integrin on B16F10 cells the immunocytochemistry (Figure 3 ) clearly demonstrate the presence of alfa5betal on the surface of the B16F10 cells.

\subsection{Effect of Black Tea Extract on ERK/PI-3K/NF- $\kappa B$}

The B16F10 cells were treated with polyphenol theaflavin at a concentration of $40 \mu \mathrm{g} / \mathrm{ml}$ for $24 \mathrm{hrs}$ in serum free culture medium (SFCM). The comparative immunoblots show that theaflavin downregulate the expression of ERK, PI-3K and NF- $\kappa$ B (Figure 4). 


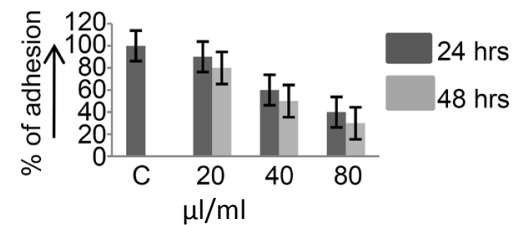

(a)

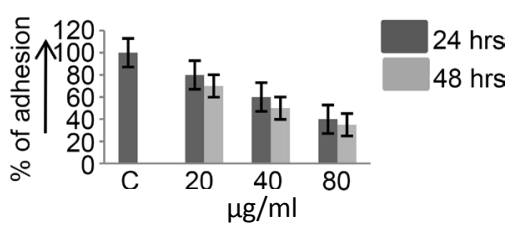

(b)

Figure 1. Cell Adhesion Assay: Cell adhesion assay of B16F10 cells treated with black tea extract for $24 \mathrm{hrs} \& 48 \mathrm{hrs}$ ((a) Control and 20/40/80 $\mu \mathrm{l} / \mathrm{ml}$ ) and with theaflavin for $24 \&$ $48 \mathrm{hrs}$; ((b) Control and 20/40/80 $\mu \mathrm{g} / \mathrm{ml}$ ) was performed following the method described in methods \& materials.

(a)

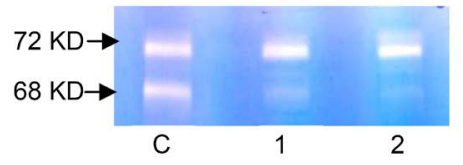

(b)

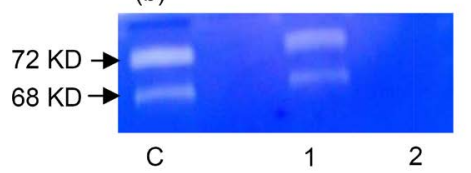

(c)

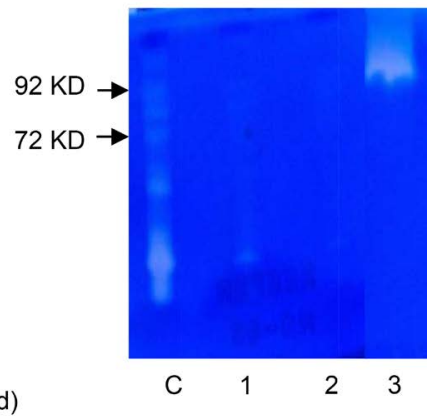

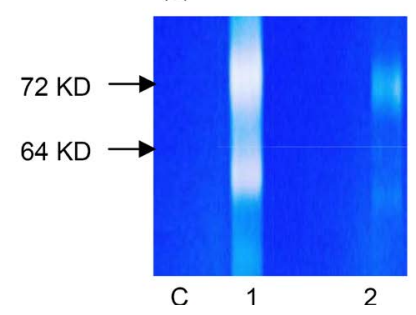

Figure 2. Zymography: Zymography of cell culture medium (FBS free DMEM) of black tea extract ((a) Control-C, $24 \mathrm{hrs}-1$ and $48 \mathrm{hrs}-2)$ and theaflavin ((b), Control-C, 24 hrs-1, $48 \mathrm{hrs}-2)$ treated B16F10 cells was done following the method described in method section. (c) Effect of black tea extract \& theaflavin (C-Control, $1-25 \mu \mathrm{l}$ tea extract, 2-50 $\mu \mathrm{l}$ tea extract, 3-theaflavin $20 \mu \mathrm{g} / \mathrm{ml}$ ) on salivary MMP following the method described in method section. (d) C-Control, 1-Fn-Cell interaction overnight, 2-Fn-cells (reacted with alfa 5 monoclonal antibody) interaction

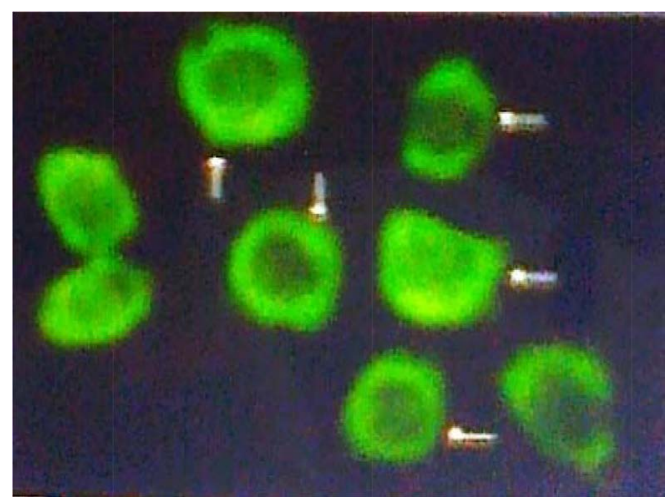

Figure 3. Immunofluorescence: B16F10 cells were grown on slide. Blocked with 3\% BSA, reacted with alfa5 monoclonal antibody followed by FITC coupled 2nd antibody. The fluorescence was observed under fluorescence microscope $\times 40$. The arrow indicates the fluorescence on cell surface. 
(a)

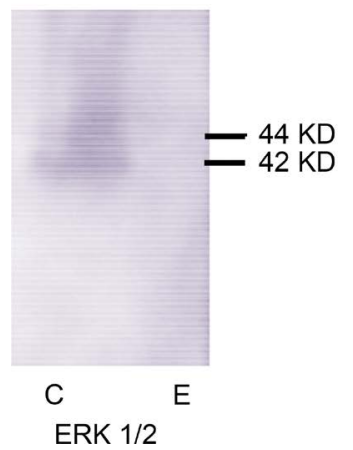

(b)

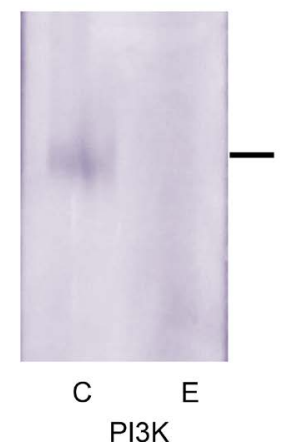

(c)

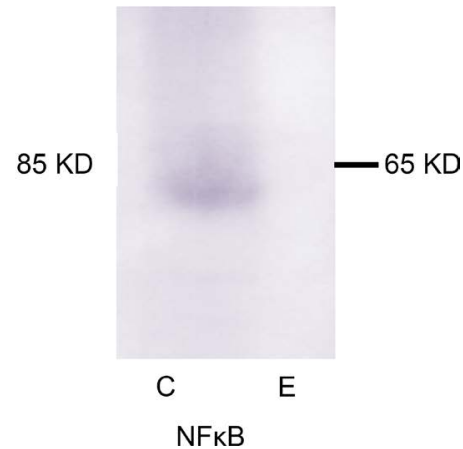

Figure 4. Immunoblot: B16F10 cells were treated with theaflavin at $40 \mu \mathrm{g} / \mathrm{ml}$ conc. The control and treated cell extract ( $100 \mu \mathrm{g}$ of protein) was run to develop immunoblot using antibodies against ERK 1/2 (a), PI- $3 \mathrm{~K}$ (b) and NF- $\kappa$ B (c) using method described in method section.

\section{Discussion}

Cell-ECM interaction is one of the fundamental aspects of developmental as well as cancer biology. We wanted to see whether black tea extract and polyphenol theaflavin has any effect on cell-ECM (Fibronectin) interaction. The findings were very meaningful. The results clearly show that the binding of black tea extract and theaflavin treated B16F10 cells reduced drastically to fibronectin (ECM) most probably via integrin alfa5beat1. Culture of B16F10 cells over fibronectin coated culture dish upregulates MMP-2 is another evidence of cell-ECM interaction in regulation of MMP-2 and the role of alfa5betal integrin in MMP-2 regulation. Interestingly, when alfa5betal integrin was capped using alfa5 antibody, the expression and activity of MMP-2 was drastically reduced indicating strongly the alfa5betal integrin mediated signalling in modulation of MMP-2 activity [38]. The MMP-2 inhibitory property of black tea polyphenols prompted us to see its effect on MMP of human source. We developed a human salivary MMP model and found that black tea extract and theaflavin inhibit the MMP-2 activity in vivo as well as in vitro indicating strongly the effect of black tea on dental health especially to protect tooth enamel. The inhibitory effect of black tea polyphenol on cell-ECM (fibronectin) interaction strongly suggests the effect on alfa5beat1 integrin mediated signalling. In a recent review, we suggested that alfa5beta1 integrin is one of the regulatory molecules of MMP-2/9 [39]. VEGF is reported to have regulatory role on MMP-2. It has been reported that tea polyphenols have inhibitory effect on VEGF [39]. TIMP-2 has also been reported to increase during black tea polyphenol treatment [39] [40] indicating strong reasons for MMP-2 inhibition. The black tea polyphenols also have inhibitory effect on cell signalling molecules [41]. Culturing B16F10 cells in presence of theaflavin for $24 \mathrm{hrs}$ inhibits the ERK, PI-3K and NF- $\kappa$ B expression appreciably. Black tea is a very good health drink. Perhaps it has no side effects. For last several years, the experiments with black tea polyphenols strengthen the data having possible anti-cancer effects. So far anti-cancer effect is concerned that the MMP inhibitory effect of tea polyphenols is most attracting because 
MMPs especially MMP-2 is sitting in a pivotal position of cancer biology and should be looked at seriously. Role of MMP 2 and 9 has been studied and reported in development of cancer by numerous researchers. Our experimental observations are in agreement with the possibility that black tea (Darjeeling variety) extract and the polyphenol theaflavin have anti-cancer potential. Whole world is looking for synthetic or organic compound(s) playing role as efficient inhibitor of MMP-2 and or MMP-9. Here in a cup of black tea we have such compound (black tea polyphenols, theaflavin) which may have some long lasting medicinal effect on tissue microenvironment in general causing prevention of onset of the disease like cancer.

\section{Acknowledgements}

We acknowledge Vice Chancellor, Ramakrishna Mission Vivekananda University, Natonal Tea Research Foundation for funding the project. Code No: NTRF 171/2014 started on June 6, 2014.

\section{Conflict of Interest}

None.

\section{References}

[1] Wu, Y.Y., Li, W., Xu, Y., Jin, E.H. and Tu, Y.Y. (2011) Evaluation of the Antioxidant Effects of Four Main Theaflavin Derivatives through Chemiluminescence and DNA Damage Analyses. Journal of Zhejiang University Science B, 12, 744. https://doi.org/10.1631/jzus.B1100041

[2] Yang, C.S., Wang, X., Lu, G. and Picinich, S.C. (2009) Cancer Prevention by Tea: Animal Studies, Molecular Mechanisms and Human Relevance. Nature Reviews Cancer, 9, 429-439. https://doi.org/10.1038/nrc2641

[3] Balentine, D.A., Wiseman, S.A. and Bouwens, L.C. (1997) The Chemistry of Tea Flavonoids. Critical Reviews in Food Science \& Nutrition, 37, 693-704. https://doi.org/10.1080/10408399709527797

[4] Miller, N.J., Castelluccio, C., Tijburg, L. and Rice-Evans, C. (1996) The Antioxidant Properties of Theaflavins and Their Gallate Esters-Radical Scavengers or Metal Chelators? FEBS Letters, 392, 40-44. https://doi.org/10.1016/0014-5793(96)00780-6

[5] Sun, C.L., Yuan, J.M., Koh, W.P. and Mimi, C.Y. (2006) Green Tea, Black Tea and Breast Cancer Risk: A Meta-Analysis of Epidemiological Studies. Carcinogenesis, 27, 1310-1315. https://doi.org/10.1093/carcin/bgi276

[6] George, J., Singh, M., Srivastava, A.K., Bhui, K., Roy, P., Chaturvedi, P.K. and Shukla, Y. (2011) Resveratrol and Black Tea Polyphenol Combination Synergistically Suppress Mouse Skin Tumors Growth by Inhibition of Activated MAPKs and p53. PLoS ONE, 6, e23395. https://doi.org/10.1371/journal.pone.0023395

[7] Roy, P., Nigam, N., George, J., Srivastava, S. and Shukla, Y. (2009) Induction of Apoptosis by Tea Polyphenols Mediated through Mitochondrial Cell Death Pathway in Mouse Skin Tumors. Cancer Biology \& Therapy, 8, 1281-1287. https://doi.org/10.4161/cbt.8.13.8728

[8] Egeblad, M. and Werb, Z. (2002) New Functions for the Matrix Metalloproteinases in Cancer Progression. Nature Reviews Cancer, 2, 161-174. 
https://doi.org/10.1038/nrc745

[9] Nagase, H., Visse, R. and Murphy, G. (2006) Structure and Function of Matrix Metalloproteinases and TIMPs. Cardiovascular Research, 69, 562-573.

https://doi.org/10.1016/j.cardiores.2005.12.002

[10] Strongin, A.Y., Collier, I., Bannikov, G., Marmer, B.L., Grant, G.A. and Goldberg, G.I. (1995) Mechanism of Cell Surface Activation of 72-kDa Type IV Collagenase Isolation of the Activated Form of the Membrane Metalloprotease. Journal of Biological Chemistry, 270, 5331-5338. https://doi.org/10.1074/jbc.270.10.5331

[11] Banerji, A., Chakrabarti, J., Mitra, A. and Chatterjee, A. (2005) Cell Membrane-Associated MT1-MMP-Dependent Activation of pro-MMP-2 in A375 Melanoma Cells. Journal of Environmental Pathology, Toxicology and Oncology, 24, 3-18. https://doi.org/10.1615/JEnvPathToxOncol.v24.i1.20

[12] Kamiya, N., Kishimoto, T., Suzuki, H., Sekita, N., Nagai, Y., Oosumi, N., Kito, H., Tochigi, N., Shinbo, M., Nemori, R. and Ichikawa, T. (2003) Increased in Situ Gelatinolytic Activity in Renal Cell Tumor Tissues Correlates with Tumor Size, Grade and Vessel Invasion. International Journal of Cancer, 106, 480-485.

https://doi.org/10.1002/ijc.11272

[13] Tester, A.M., Waltham, M., Oh, S.J., Bae, S.N., Bills, M.M., Walker, E.C., Kern, F.G., Stetler-Stevenson, W.G., Lippman, M.E. and Thompson, E.W. (2004) Pro-Matrix Metalloproteinase-2 Transfection Increases Orthotopic Primary Growth and Experimental Metastasis of MDA-MB-231 Human Breast Cancer Cells in Nude Mice. Cancer Research, 64, 652-658. https://doi.org/10.1158/0008-5472.CAN-0384-2

[14] Yoon, S.O., Park, S.J., Yun, C.H. and Chung, A.S. (2003) Roles of Matrix Metalloproteinases in Tumor Metastasis and Angiogenesis. Journal of Biochemistry and Molecular Biology, 36, 128-137.

[15] Ann Beltz, L., Kay Bayer, D., Lynn Moss, A. and Mitchell Simet, I. (2006) Mechanisms of Cancer Prevention by Green and Black Tea Polyphenols. Anti-Cancer Agents in Medicinal Chemistry (Formerly Current Medicinal Chemistry-AntiCancer Agents), 6, 389-406.

[16] Sazuka, M., Imazawa, H., Shoji, Y., Mita, T., Hara, Y. and Isemura, M. (1997) Inhibition of Collagenases from Mouse Lung Carcinoma Cells by Green Tea Catechins and Black Tea Theaflavins. Bioscience, Biotechnology, and Biochemistry, 61, 1504 1506. https://doi.org/10.1271/bbb.61.1504

[17] Sil, H., Sen, T., Moulik, S. and Chatterjee, A. (2010) Black Tea Polyphenol (Theaflavin) Downregulates MMP-2 in Human Melanoma Cell Line A375 by Involving Multiple Regulatory Molecules. Journal of Environmental Pathology, Toxicology and Oncology, 29, 55-68.

https://doi.org/10.1615/JEnvironPatholToxicolOncol.v29.i1.80

[18] Herbst, R.S. (2004) Review of Epidermal Growth Factor Receptor Biology. International Journal of Radiation Oncology ${ }^{\star}$ Biology ${ }^{\star}$ Physics, 59, S21-S26.

https://doi.org/10.1016/j.ijrobp.2003.11.041

[19] Olayioye, M.A., Neve, R.M., Lane, H.A. and Hynes, N.E. (2000) The ErbB Signaling Network: Receptor Heterodimerization in Development and Cancer. The EMBO Journal, 19, 3159-3167. https://doi.org/10.1093/emboj/19.13.3159

[20] Seshacharyulu, P., Ponnusamy, M.P., Haridas, D., Jain, M., Ganti, A.K. and Batra, S.K. (2012) Targeting the EGFR Signaling Pathway in Cancer Therapy. Expert Opinion on Therapeutic Targets, 16, 15-31. https://doi.org/10.1517/14728222.2011.648617

[21] Mizuno, H., Cho, Y.Y., Zhu, F., Ma, W.Y., Bode, A.M., Yang, C.S., Ho, C.T. and Dong, Z. (2006) Theaflavin-3, 3'-Digallate Induces Epidermal Growth Factor Re- 
ceptor Downregulation. Molecular carcinogenesis, 45, 204-212. https://doi.org/10.1002/mc.20174

[22] Juliano, R.L. (2002) Signal Transduction by Cell Adhesion Receptors and the Cytoskeleton: Functions of Integrins, Cadherins, Selectins, and Immunoglobulin-Superfamily Members. Annual Review of Pharmacology and Toxicology, 42, 283-323. https://doi.org/10.1146/annurev.pharmtox.42.090401.151133

[23] Jin, H. and Varner, J. (2004) Integrins: Roles in Cancer Development and as Treatment Targets. British Journal of Cancer, 90, 561-565. https://doi.org/10.1038/sj.bjc.6601576

[24] Liotta, L.A., Nageswara Rao, C. and Wewer, U.M. (1986) Biochemical Interactions of Tumor Cells with the Basement Membrane. Annual Review of Biochemistry, 55, 1037-1057. https://doi.org/10.1146/annurev.bi.55.070186.005133

[25] Pasquier, E., Andre, N. and Braguer, D. (2007) Targeting Microtubules to inhIbit Angiogenesis and Disrupt Tumour Vasculature: Implications for Cancer Treatment. Current Cancer Drug Targets, 7, 566-581. https://doi.org/10.2174/156800907781662266

[26] Chakrabarty, S., Das, A., Bhattacharya, A. and Chakrabarti, G. (2011) Theaflavins Depolymerize Microtubule Network through Tubulin Binding and Cause Apoptosis of Cervical Carcinoma HeLa Cells. Journal of Agricultural and Food Chemistry, 59, 2040-2048. https://doi.org/10.1021/jf104231b

[27] Sieg, D.J., Hauck, C.R., Ilic, D., Klingbeil, C.K., Schaefer, E., Damsky, C.H. and Schlaepfer, D.D. (2000) FAK Integrates Growth-Factor and Integrin Signals to Promote Cell Migration. Nature Cell Biology, 2, 249-256. https://doi.org/10.1038/35010517

[28] Sieg, D.J., Hauck, C.R. and Schlaepfer, D.D. (1999) Required Role of Focal Adhesion Kinase (FAK) for Integrin-Stimulated Cell Migration. Journal of Cell Science, 112, 2677-2691.

[29] Weber, W.M., Hunsaker, L.A., Roybal, C.N., Bobrovnikova-Marjon, E.V., Abcouwer, S.F., Royer, R.E., Deck, L.M. and Vander Jagt, D.L. (2006) Activation of NF $\kappa$ B Is Inhibited by Curcumin and Related Enones. Bioorganic \& Medicinal Chemistry, 14, 2450-2461.

[30] Gosslau, A., Jao, E., Li, D., Huang, M.T., Ho, C.T., Evans, D., Rawson, N.E. and Chen, K.Y. (2011) Effects of the Black Tea Polyphenol Theaflavin-2 on Apoptotic and Inflammatory Pathways in Vitro and in Vivo. Molecular Nutrition \& Food Research, 55, 198-208. https://doi.org/10.1002/mnfr.201000165

[31] Kim, S. and Joo, Y.E. (2011) Theaflavin Inhibits LPS-Induced IL-6, MCP-1, and ICAM-1 Expression in Bone Marrow-Derived Macrophages through the Blockade of NF- $\kappa$ B and MAPK Signaling Pathways. Chonnam Medical Journal, 47, 104-110. https://doi.org/10.4068/cmj.2011.47.2.104

[32] Khan, N., Afaq, F. and Mukhtar, H. (2008) Cancer Chemoprevention through Dietary Antioxidants: Progress and Promise. Antioxidants \& Redox Signaling, 10, 475 510. https://doi.org/10.1089/ars.2007.1740

[33] Ukil, A., Maity, S. and Das, P.K. (2006) Protection from Experimental Colitis by Theaflavin-3,3'-Digallate Correlates with Inhibition of IKK and NF- $\kappa$ B Activation. British journal of Pharmacology, 149, 121-131. https://doi.org/10.1038/sj.bjp.0706847

[34] Chung, J.Y., Park, J.O., Phyu, H., Dong, Z. and Yang, C.S. (2001) Mechanisms of Inhibition of the Ras-MAP Kinase Signaling Pathway in 30.7 b Ras 12 Cells by Tea Polyphenols (-)-Epigallocatechin-3-Gallate and Theaflavin-3,3'-Digallate. The FASEB Journal, 15, 2022-2024. 
[35] Agarwal, M.L., Taylor, W.R., Chernov, M.V., Chernova, O.B. and Stark, G.R. (1998) The p53 Network. Journal of Biological Chemistry, 273, 1-4. https://doi.org/10.1074/jbc.273.1.1

[36] Kalra, N., Seth, K., Prasad, S., Singh, M., Pant, A.B. and Shukla, Y. (2007) Theaflavins Induced Apoptosis of LNCaP Cells Is Mediated through Induction of p53, Down-Regulation of NF-Kappa B and Mitogen-Activated Protein Kinases Pathways. Life Sciences, 80, 2137-2146.

[37] Lahiry, L., Saha, B., Chakraborty, J., Bhattacharyya, S., Chattopadhyay, S., Banerjee, S., Choudhuri, T., Mandal, D., Bhattacharyya, A., Sa, G. and Das, T. (2008) Contribution of p53-Mediated Bax Transactivation in Theaflavin-Induced Mammary Epithelial Carcinoma Cell Apoptosis. Apoptosis, 13, 771-781.

https://doi.org/10.1007/s10495-008-0213-x

[38] Kundu, T., Dey, S., Roy, M., Siddiqi, M. and Bhattacharya, R.K. (2005) Induction of Apoptosis in Human Leukemia Cells by Black Tea and Its Polyphenol Theaflavin. Cancer Letters, 230, 111-121. https://doi.org/10.1016/j.canlet.2004.12.035

[39] Pal, S., Kumar Ganguly, K., Moulik, S. and Chatterjee, A. (2012) Modulation of MMPs by Cell Surface Integrin Receptor $\alpha 5 \beta 1$. Anti-Cancer Agents in Medicinal Chemistry (Formerly Current Medicinal Chemistry-Anti-Cancer Agents), 12, 726 732. https://doi.org/10.2174/187152012802650183

[40] Murugan, R.S., Vinothini, G., Hara, Y. and Nagini, S. (2009) Black Tea Polyphenols Target Matrix Metalloproteinases, RECK, Proangiogenic Molecules and Histone Deacetylase in a Rat Hepatocarcinogenesis Model. Anticancer Research, 29, 2301 2305.

[41] Hou, Z., Lambert, J.D., Chin, K.V. and Yang, C.S. (2004) Effects of Tea Polyphenols on Signal Transduction Pathways Related to Cancer Chemoprevention. Mutation Research/ Fundamental and Molecular Mechanisms of Mutagenesis, 555, 3-19.

\section{Submit or recommend next manuscript to SCIRP and we will provide best service for you:}

Accepting pre-submission inquiries through Email, Facebook, LinkedIn, Twitter, etc. A wide selection of journals (inclusive of 9 subjects, more than 200 journals)

Providing 24-hour high-quality service

User-friendly online submission system

Fair and swift peer-review system

Efficient typesetting and proofreading procedure

Display of the result of downloads and visits, as well as the number of cited articles

Maximum dissemination of your research work

Submit your manuscript at: http://papersubmission.scirp.org/

Or contact ajps@scirp.org 